\title{
THE IMPACT OF FINANCIAL FACTORS ON THE OUTPUT GAP AND ESTIMATES OF POTENTIAL OUTPUT GROWTH
}

Jesus Felipe, Noli Sotocinal, and Connie Bayudan-Dacuycuy

NO. 457

October 2015
ADB ECONOMICS WORKING PAPER SERIES 
ADB Economics Working Paper Series

\section{The Impact of Financial Factors on the Output Gap and Estimates of Potential Output Growth}

Jesus Felipe, Noli Sotocinal, and Connie Bayudan-Dacuycuy

No. 457 | October 2015
Jesus Felipe (jfelipe@adb.org) is Advisor and Noli Sotocinal (nsotocinal@adb.org) is Senior Economics Officer at the Economic Research and Regional Cooperation Department, Asian Development Bank (ADB). Connie Bayudan-Dacuycuy (cbayudandacuycuy@ateneo.edu) is Assistant Professor at the Economics Department, Ateneo de Manila University.

We are indebted to Piti Disyatat of the Bank of Thailand and Mikael Juselius of the Bank of Finland for sharing with us the Matlab code of the method explained in Borio, Disyatat, and Juselius (2013) and for clarifying questions on the methodology. Nevertheless, we are solely responsible for any errors. 
Asian Development Bank

6 ADB Avenue, Mandaluyong City

1550 Metro Manila, Philippines

www.adb.org

(C) 2015 by Asian Development Bank

October 2015

ISSN 2313-6537 (Print), 2313-6545 (e-ISSN)

Publication Stock No. WPS157673-2

The views expressed in this paper are those of the authors and do not necessarily reflect the views and policies of the Asian Development Bank (ADB) or its Board of Governors or the governments they represent.

ADB does not guarantee the accuracy of the data included in this publication and accepts no responsibility for any consequence of their use.

By making any designation of or reference to a particular territory or geographic area, or by using the term "country" in this document, $A D B$ does not intend to make any judgments as to the legal or other status of any territory or area.

Note: In this publication, "\$” refers to US dollars.

The ADB Economics Working Paper Series is a forum for stimulating discussion and eliciting feedback on ongoing and recently completed research and policy studies undertaken by the Asian Development Bank (ADB) staff, consultants, or resource persons. The series deals with key economic and development problems, particularly those facing the Asia and Pacific region; as well as conceptual, analytical, or methodological issues relating to project/program economic analysis, and statistical data and measurement. The series aims to enhance the knowledge on Asia's development and policy challenges; strengthen analytical rigor and quality of ADB's country partnership strategies, and its subregional and country operations; and improve the quality and availability of statistical data and development indicators for monitoring development effectiveness.

The ADB Economics Working Paper Series is a quick-disseminating, informal publication whose titles could subsequently be revised for publication as articles in professional journals or chapters in books. The series is maintained by the Economic Research and Regional Cooperation Department. 


\section{CONTENTS}

TABLES AND FIGURES $\quad$ iv

ABSTRACT V V

$\begin{array}{ll}\text { I. INTRODUCTION } & 1\end{array}$

II. EMBEDDING FINANCIAL FACTORS IN ESTIMATES OF THE OUTPUT GAP
AND OUTPUT POTENTIAL

III. $\quad$ ESTIMATION RESULTS FOR THE G-5 ECONOMIES

IV. ESTIMATION RESULTS FOR THE ASIAN ECONOMIES

V. CONCLUSIONS

$\begin{array}{ll}\text { REFERENCES } & 17\end{array}$ 


\section{TABLES AND FIGURES}

\section{TABLES}

$1 \quad$ Descriptive Statistics 4

2 Impact of Financial Factors on the Output Gap for G-5 Countries 7

3 Average Actual and Potential Output Growth of G-5 Countries 10

$4 \quad$ Estimation Results: Impact of Individual Financial Factors

for High-Income Asian Economies

$5 \quad$ Estimation Results: Impact of Individual Financial Factors

for Middle-Income Asian Economies

6 Average Actual and Potential Output Growth of Selected Asian Economies 15

\section{FIGURES}

$1 \quad$ Real Credit Growth, Property Price Inflation, and Real Interest Rates 5

2 Actual and Estimated Potential Growth of G-5 Countries 8

Actual and Estimated Potential Growth of High- and Middle-
Income Asian Economies 


\begin{abstract}
The literature on the finance-growth nexus highlights the importance of the financial cycle for the estimation of potential output of an economy. We estimate potential output growth for the G-5 countries, as well as for 10 high- and middle-income Asian economies, using a multivariate model that includes financial factors. We find that the latter have a positive and statistically significant effect on the output gap of the G-5 and high-income Asian economies, but not on that of the middle-income Asian economies. We also find that average potential growth of the economies included in the study is lower in 2008-2014 than in 2000-2007.
\end{abstract}

Keywords: economic growth, financial factors, output gaps, potential output growth

JEL Classification: E32, G00, O11, O16, O47 
"where enterprise leads, finance follows"

- Joan Robinson (1952)

\section{INTRODUCTION}

In a recent paper, Borio, Disyatat, and Juselius (2013) propose a framework to estimate the output gap and potential output by embedding financial cycle information into their model. They argue that financial cycles contain information relevant to the estimation of output gaps and potential output.

Borio, Disyatat, and Juselius (2013) define potential output as the level of output that is consistent with maximum sustainable employment. They note, however, that sustainability is a modeldependent concept, closely tied to that of equilibrium, where output, employment, and inflation tend to remain stable. The definition of potential output as well its relationship with unemployment and inflation have evolved since it was introduced by Okun (1962), and is currently viewed to be the level of production output that is consistent with the level of employment that results in a nonaccelerating rate of inflation. This implies that inflation accelerates when actual output is above its potential level, and decelerates when it is below potential output.

Borio, Disyatat, and Juselius (2013), however, note that real output can grow in an unsustainable manner even under low and stable inflation. They point out the importance of financial factors and financial development in the determination of long-term output, and that these factors can have permanent effects on output. 'There is also a growing literature on the interrelationship between financial cycles, business cycles, and financial crises that shows that there is a procyclical relationship between financial factors and deviations of actual output from its potential. Cecchetti and Kharroubi (2015), for example, show that excessive growth in the finance sector can negatively impact real output growth due to resource misallocation; while Law and Singh (2014) show that finance can only be beneficial to output growth up to a certain threshold, beyond which it can crowd out real output growth. Rousseau and Wachtel (2002) also examine the interplay between financial development and growth, and extend the analysis to different inflationary conditions. They find that the impact of financial development on output growth interacts with the inflation rate such that when inflation exceeds a particular threshold rate, financial factors no longer positively affect real output growth. Claessens, Kose, and Terrones (2011) examine over 200 business cycles and 700 financial cycles in 44 economies during 1960-2007 and find that financial cycles tend to magnify the dynamics of real output throughout the course of the business cycle. The foregoing suggests that financial factors have permanent and cyclical effects on output growth, with the implication that singling out inflation as the only criterion for the sustainability of output may be too restrictive.

Given the empirical evidence about the influence of financial factors on real output, Borio, Disyatat, and Juselius (2013) argue that financial cycles contain important information relevant to the estimation of the output gap and potential output. They assert, therefore, that using financial information enhances the quality of the estimates. The ease of obtaining credit during periods of financial booms, for example, tends to relax supply-side constraints and leads to unsustainable increases in output without increasing price levels. Easy credit conditions also favor sectors that are most sensitive to credit, leading to unsustainable increases in output due to resource misallocation. The asset price inflation that accompanies financial booms also tends to encourage a surge in capital inflows and causes a real exchange rate appreciation, which dampens imported price inflation.

\footnotetext{
See, for example, King and Levine (1993), Carlin and Mayer (2003), Rioja and Valev (2004), Jude (2010).
} 
Following Borio, Disyatat, and Juselius (2013), this paper examines the impact of financial factors on the output gap, and extends the scope of their empirical work to the G-5 and 10 high- and middle-income economies in Asia. The remainder of the paper is structured as follows. Section II briefly presents the framework to analyze the impact of financial factors on the output gap and estimates potential output. Section III and IV present the results of our empirical analyses for the G-5 and for 10 high- and middle-income economies in Asia. Section $\vee$ presents our conclusions.

\section{EMBEDDING FINANCIAL FACTORS IN ESTIMATES OF THE OUTPUT GAP AND OUTPUT POTENTIAL}

To examine the usefulness of the informational content of financial factors for the measurement of the output gap and potential output, Borio, Disyatat, and Juselius (2013) start with a univariate statespace model of actual and potential output. Equation (1) relates changes in potential output to its past values as a covariance-stationary random walk, and is defined by the following transition equation:

$$
\Delta y_{t}^{*}=\Delta y_{t-1}^{*}+\varepsilon_{0, t}
$$

where $y_{t}^{*}$ is the logarithm of potential output at time $t$ and $\Delta$ denotes first difference. It is assumed that $\varepsilon_{0, t} \sim \operatorname{iid}\left(0, \sigma_{0}^{2}\right)$.

The measurement equation defined by Equation (2) relates real output to potential output as:

$$
y_{t}=y_{t}^{*}+\varepsilon_{1, t}
$$

where, $y_{t}$ is the logarithm of real output. It is assumed that $\varepsilon_{1, t} \sim \operatorname{iid}\left(0, \sigma_{1}^{2}\right)$ and $\operatorname{Cov}\left(\varepsilon_{0, t}, \varepsilon_{1, t}\right)=0$. The estimation of potential output and output gap using the state-space model defined by Equations (1) and (2) relies only on observations of actual output. Borio, Disyatat, and Juselius (2014, p. 5), however, note that the resulting estimates from this model specification provide a "poor representation of the data," since Equation (2) implies that the difference between actual and potential output (i.e., the output gap) is white noise. They opine that the output gap does not behave like white noise, but is correlated with other economic indicators such as inflation and employment. As such, the state-space model specification defined by Equations (1) and (2) could be enhanced by embedding additional information from other economic indicators.

Borio, Disyatat, and Juselius (2013) modify Equation (2) by transposing potential output to the left-hand side, and converting it into an expression for the output gap. They then add financial factors such as changes in real credit and in property prices, and real interest rates, as explanatory variables of the output gap, and add a lagged term of the output gap to account for possible persistence. ${ }^{2}$ These modifications transform Equation (2) into the following measurement equation for the output gap:

$$
y_{g a p, t}=y_{t}-y_{t}^{*}=\beta \cdot\left(y_{t-1}-y_{t-1}^{*}\right)+\gamma_{1} \cdot \Delta c r_{t}+\gamma_{2} \cdot \Delta p h_{t}+\gamma_{3} \cdot r_{t}+\varepsilon_{2, t}
$$

\footnotetext{
2 Borio Disyatat and M. Juselius (2013) note that the addition of a lagged or autoregressive term for the output gap also
} captures any possible permanent or highly persistent effects of financial factors. 
where $\Delta c r_{t}$ and $\Delta p h_{t}$ is the change in real credit and real property price inflation at time $t$, respectively, and $r_{t}$ is the real interest rate at time $t$. It is assumed that $\varepsilon_{2, t} \sim i i d\left(0, \sigma_{2}^{2}\right)$ and $\operatorname{Cov}\left(\varepsilon_{0, t}, \varepsilon_{2, t}\right)=0 .{ }^{3}$

Equations (1) and (3) are the transition and measurement equations of a multivariate statespace model of actual and potential output. Borio, Disyatat, and Juselius (2013) estimate the parameters of Equation (3) and potential output in two stages. In the first stage, they use Bayesian methods to estimate the parameters of Equation (3). ${ }^{4}$ They then estimate potential output $y_{t}^{*}$ using the Kalman filter in the second stage. The multivariate state-space model specification in the second stage utilizes the estimates of the coefficients of the financial factors; $\hat{\beta}, \widehat{\gamma_{1}}, \widehat{\gamma_{2}}$, and $\widehat{\gamma_{3}}$ obtained in the first stage in measurement Equation (3), and uses Equation (1) as the transition equation.

We apply this framework to estimate potential output growth and to assess the impact of financial factors on the estimates of the output gap for the G-5 economies (the United States [US], the United Kingdom [UK], Germany, France, and Japan) and for 10 high- and middle-income Asian economies (the Republic of Korea; the People's Republic of China [PRC]; Hong Kong, China; Taipei,China; Singapore; India; Indonesia; Malaysia; the Philippines; and Thailand). Following Borio, Disyatat, and Juselius (2013), we use the change in real credit, change in real property prices and real interest rates as proxy variables for the financial cycle. Quarterly data on credit and property prices were obtained primarily from the Bank of International Settlements (BIS) online database. ${ }^{5}$ For economies that do not have credit and property price data in the BIS database, the data from the economies' respective monetary authorities are used. The Data on real output, the gross domestic product deflator, the consumer price index, and interest rates were downloaded from the CEIC Data Company database. ${ }^{6}$ We divide nominal credit by the price deflator to derive real credit, and use the consumer price index to derive real property prices and the real interest rate. ${ }^{7}$ All variables are deseasonalized, logarithmically transformed, and are adjusted for Cesaro means. ${ }^{8}$

Table 1 shows the mean and standard deviation of real output, changes in real credit, real property price inflation, and real interest rate for the G-5 and 10 Asian high- and middle-income economies, before adjustment for Cesaro means.

Note from Table 1 that except for Thailand, the mean real credit growth of the G-5 economies are generally lower and less volatile compared to the Asian economies. Average real property price inflation is generally lower than mean real credit growth, except for Hong Kong, China and Singapore. The standard deviations of real credit growth are larger than those of real property price inflation for the Asian economies, except for Hong Kong, China and Singapore. The extent of volatility of financial factors is easily seen in Figure 1.

3 Like Borio, Disyatat, and Juselius (2013), we estimated the measurement equation defined by (3) with the inflation rate as an added explanatory variable for the output gap, but obtained statistically insignificant estimates for its coefficient.

4 Borio, Disyatat, and Juselius (2013) use the Gamma distribution as the prior distribution of $\beta, \gamma_{1}, \gamma_{2}$, and $\gamma_{3}$, and restrict the estimate of $\beta$ to lie between 0 and 0.95 to preclude a unit root in the output gap estimates. The values of the parameters of the financial factors are similarly restricted to lie between 0 and 1.

5 The BIS online database (http://www.bis.org/statistics/) was last accessed on 28 July 2015. Credit is defined as claims of the finance sector on the private, nonfinance sector. Property prices are country-level price indices on real property.

6 The CEIC database was last accessed on 05 August 2015.

7 We use the following expressions to compute changes in real credit, real property price inflation and real interest rates, respectively: $\Delta c r_{t}=\Delta \log \left(\frac{\text { nominal credit }}{t}\right), \Delta p h_{t}=\Delta \log \left(\frac{\text { property } \text { price }_{t}}{{\text { cpi } i_{t}}_{t}}\right)$, and $r_{t}=\log \left(\frac{{\text { short-term } \text { interest rate }_{t}}_{t}}{\text { cpi }_{t}}\right)$.

8 Cesaro means are sequences of moving averages of a time series data. 
Table 1: Descriptive Statistics

\begin{tabular}{|c|c|c|c|c|c|c|c|}
\hline Economy & Variable & Mean & $\begin{array}{l}\text { Standard } \\
\text { Deviation }\end{array}$ & Economy & Variable & Mean & $\begin{array}{l}\text { Standard } \\
\text { Deviation }\end{array}$ \\
\hline \multirow{4}{*}{ United States } & $y_{t}(2010)$ & 10,902 & 2,955 & \multirow{4}{*}{ Hong Kong, China } & $y_{t}(2012)$ & 310.5 & 130.8 \\
\hline & $\Delta c r_{t}$ & $4.4 \%$ & $4.7 \%$ & & $\Delta c r_{t}$ & $9.6 \%$ & $10.8 \%$ \\
\hline & $\Delta p h_{t}$ & $-0.4 \%$ & $3.97 \%$ & & $\Delta p h_{t}$ & $4.6 \%$ & $17.8 \%$ \\
\hline & $\Delta r_{t}$ & $1.4 \%$ & $2.3 \%$ & & $\Delta r_{t}$ & $0.3 \%$ & $4.4 \%$ \\
\hline \multirow{4}{*}{ Germany } & $y_{t}(2007)$ & 595.8 & 54.2 & \multirow{4}{*}{$\begin{array}{l}\text { People's Republic } \\
\text { of China }\end{array}$} & $y_{t}(2010)$ & $4,438.2$ & $1,900.5$ \\
\hline & $\Delta C r_{t}$ & $1.7 \%$ & $2.6 \%$ & & $\Delta C r_{t}$ & $13.7 \%$ & $9.4 \%$ \\
\hline & $\Delta p h_{t}$ & $-0.80 \%$ & $2.2 \%$ & & $\Delta p h_{t}$ & na & na \\
\hline & $\Delta r_{t}$ & $2.5 \%$ & $1.5 \%$ & & $\Delta r_{t}$ & $1.1 \%$ & $2.2 \%$ \\
\hline \multirow{4}{*}{ France } & $y_{t}(2006)$ & 276.2 & 161.7 & \multirow{4}{*}{ India } & $y_{t}(2010)$ & $14,312.7$ & $5,431.3$ \\
\hline & $\Delta c r_{t}$ & $3.9 \%$ & $3.2 \%$ & & $\Delta c r_{t}$ & $12.3 \%$ & $6.1 \%$ \\
\hline & $\Delta p h_{t}$ & $-0.7 \%$ & $3.9 \%$ & & $\Delta p h_{t}$ & na & na \\
\hline & $\Delta r_{t}$ & $1.9 \%$ & $2.8 \%$ & & $\Delta r_{t}$ & $1.2 \%$ & $3.6 \%$ \\
\hline \multirow{4}{*}{ United Kingdom } & $y_{t}(2011)$ & 265.2 & 92.8 & \multirow{4}{*}{ Philippines } & $y_{t}(2000)$ & $1,019.1$ & 352.1 \\
\hline & $\Delta c r_{t}$ & $5.5 \%$ & $6.6 \%$ & & $\Delta c r_{t}$ & $6.2 \%$ & $6.7 \%$ \\
\hline & $\Delta p h_{t}$ & $2.9 \%$ & $8.3 \%$ & & $\Delta p h_{t}$ & na & na \\
\hline & $\Delta r_{t}$ & $2.3 \%$ & $8.1 \%$ & & $\Delta r_{t}$ & $7.7 \%$ & $5.6 \%$ \\
\hline \multirow{4}{*}{ Japan } & $y_{t}(1990)$ & $424,838.4$ & $104,821.9$ & \multirow{4}{*}{ Indonesia } & $y_{t}(2010)$ & $1,098,899$ & 489,839 \\
\hline & $\Delta c r_{t}$ & $1.7 \%$ & $3.5 \%$ & & $\Delta c r_{t}$ & $10.0 \%$ & $20.0 \%$ \\
\hline & $\Delta p h_{t}$ & $-5.3 \%$ & $6.2 \%$ & & $\Delta p h_{t}$ & $-2.3 \%$ & $4.2 \%$ \\
\hline & $\Delta r_{t}$ & $0.1 \%$ & $1.1 \%$ & & $\Delta r_{t}$ & $2.1 \%$ & $6.7 \%$ \\
\hline \multirow{4}{*}{ Republic of Korea } & $y_{t}(2010)$ & $209,714.3$ & $88,320.3$ & \multirow{4}{*}{ Malaysia } & $y_{t}(2010)$ & 60.5 & 20.1 \\
\hline & $\Delta c r_{t}$ & $8.9 \%$ & $5.9 \%$ & & $\Delta c r_{t}$ & $7.3 \%$ & $9.4 \%$ \\
\hline & $\Delta p h_{t}$ & $-0.4 \%$ & $6.8 \%$ & & $\Delta p h_{t}$ & $3.2 \%$ & $3.7 \%$ \\
\hline & $\Delta r_{t}$ & $5.2 \%$ & $3.7 \%$ & & $\Delta r_{t}$ & $1.1 \%$ & $1.5 \%$ \\
\hline \multirow{4}{*}{ Taipei,China } & $y_{t}(1992)$ & $2,149.7$ & 992.4 & \multirow{4}{*}{ Thailand } & $y_{t}(2002)$ & $1,632.6$ & 379.2 \\
\hline & $\Delta c r_{t}$ & $9.7 \%$ & $9.2 \%$ & & $\Delta c r_{t}$ & $1.5 \%$ & $15.1 \%$ \\
\hline & $\Delta p h_{t}$ & $1.5 \%$ & $7.6 \%$ & & $\Delta p h_{t}$ & $-2.3 \%$ & $8.4 \%$ \\
\hline & $\Delta r_{t}$ & $2.0 \%$ & $2.1 \%$ & & $\Delta r_{t}$ & $-0.2 \%$ & $1.9 \%$ \\
\hline \multirow{4}{*}{ Singapore } & $y_{t}(2007)$ & 38.9 & 26.8 & & & & \\
\hline & $\Delta c r_{t}$ & $9.3 \%$ & $6.9 \%$ & & & & \\
\hline & $\Delta p h_{t}$ & $6.9 \%$ & $19.9 \%$ & & & & \\
\hline & $\Delta r_{t}$ & $0.0 \%$ & $2.4 \%$ & & & & \\
\hline
\end{tabular}

Notes:

1. $y_{t}$ is real GDP with base year enclosed in parenthesis; $\Delta c r_{t}$ is change in real credit; $\Delta p h_{t}$ is real property price inflation; $\Delta r_{t}$ is the real interest rate.

2. Real GDP is expressed in billions of local currency; Germany and France real GDP are in billions of euros.

3. Sample periods by economy are: (i) United States, Q1 1980-Q4 2012; (ii) Germany, Q1 1991-Q4 2014; (iii) France, Q1 1970-Q4 2014; (iv) United Kingdom, Q1 1963-Q1 2015; (v) Japan, Q1 1977-Q1 2015; (vi) Republic of Korea, Q1 1986-Q1 2015; (vii) Taipei,China, Q1 1982-Q1 2015;

(viii) Singapore, Q1 1975-Q1 2015; (ix) Hong Kong, China, Q4 1979-Q1 2015; (x) People’s Republic of China, Q1 1999-Q4 2014; India Q4 1996-Q1 2015; (xi) Philippines, Q1 1987-Q1 2015; (xii) Indonesia, Q1 1983-Q1 2015; (xiii) Malaysia, Q4 1990-Q4 2014; and (xiv) Thailand, Q1 $1993-Q 42014$. Source: Authors' calculations. 
Figure 1: Real Credit Growth, Property Price Inflation, and Real Interest Rates
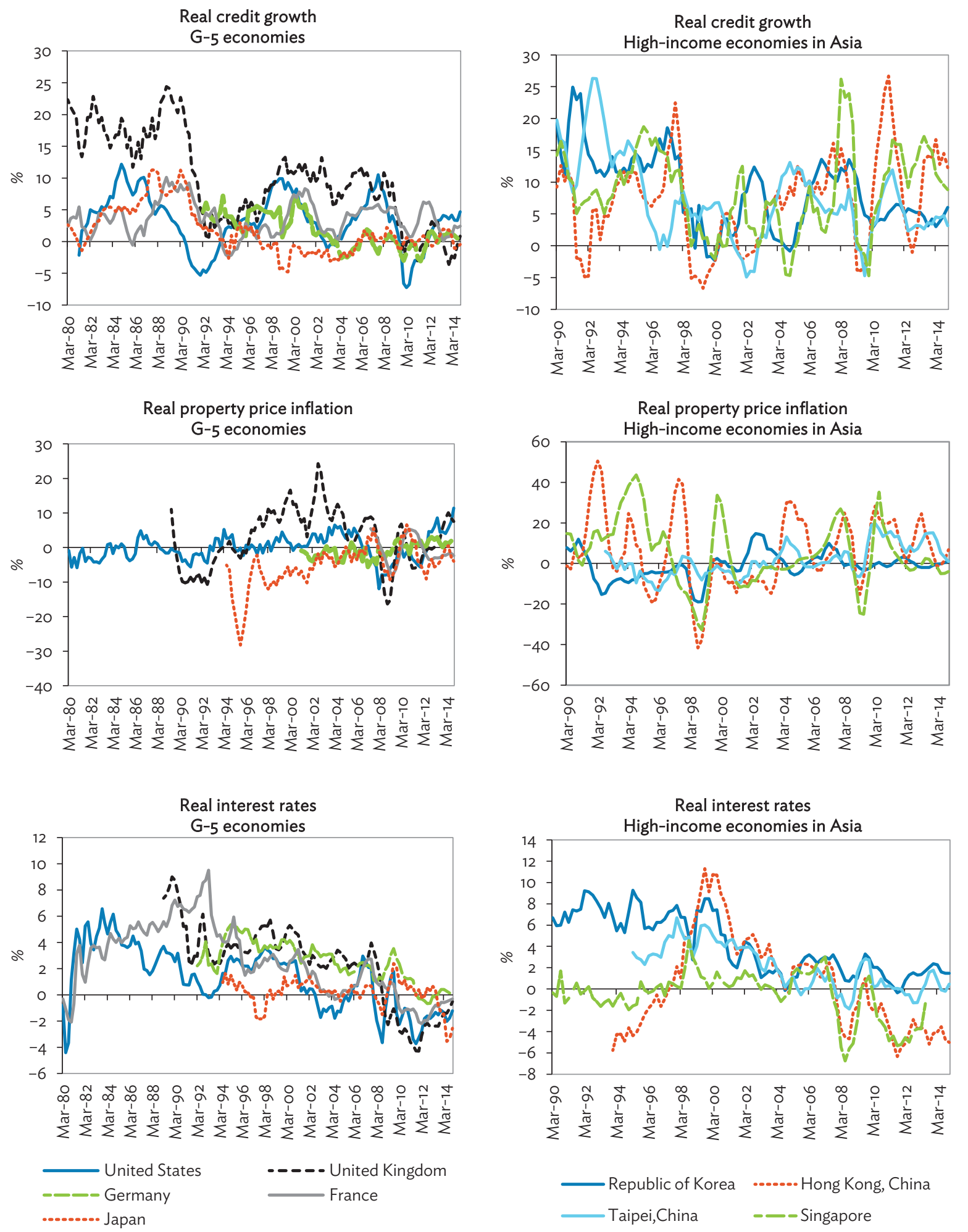
Figure 1 continued

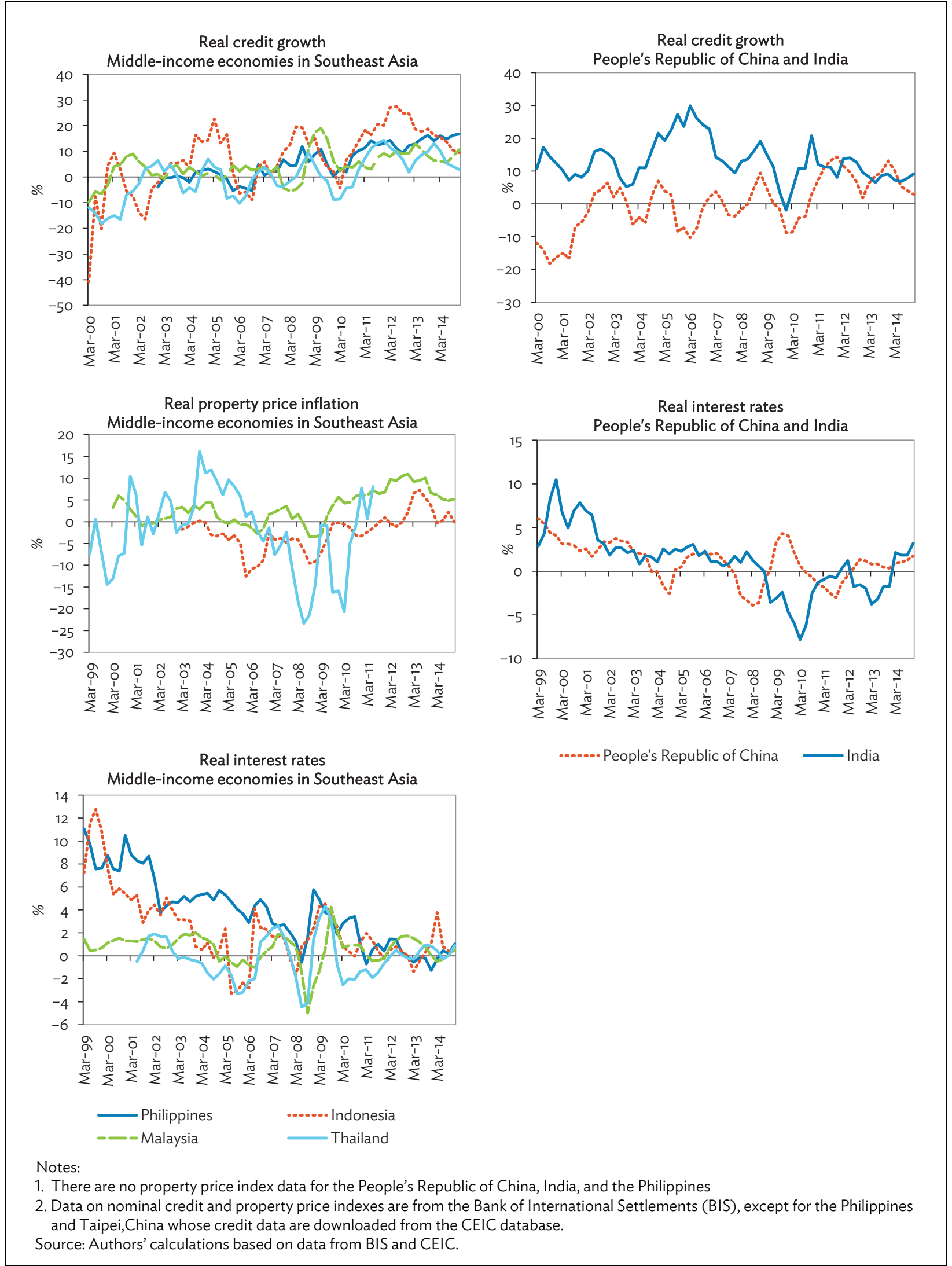


For the G-5 economies, real credit growth is more volatile in the UK, the US, and France than in Germany and Japan. Property price inflation is higher and more volatile in the UK, and has generally declined after the Global Financial Crisis (GFC) in 2008-2009. The real interest rates in the G-5 show a secular decline from the early 1990s, and turned negative for all economies during and after the GFC.

The high-income economies in Asia exhibit a very cyclical movement in real credit growth and property price inflation. Hong Kong, China and Singapore show markedly higher volatility in real credit growth and property price inflation than the Republic of Korea and Taipei,China. Like the G-5 economies, the real interest rates in Asia's high income economies have been declining since the late 1990s. The cyclicality of real credit growth and real property price inflation in Asia's middle-income economies are likewise higher than those of the G-5. Real interest rates generally show a secular declining trend from the late 1990s up to the GFC, and hovered around 0\% from 2012 to 2014.

We estimate Equation (3) by entering each financial factor separately, such that Model 1 in Table 1 uses real credit growth alone as a financial factor; (ii) Model 2 uses the real property price inflation alone; and (iii) Model 3 uses the real interest rate only. The last three rows $\left(k_{c r}, k_{p h}\right.$, and $\left.k_{r}\right)$ show the length of the lag of the respective financial factor for each model specification: real credit growth, real property price inflation, and real interest rates, respectively. Following Borio, Disyatat, and Juselius (2013), the lag lengths for the financial cycle variables denoted by $k_{c r}, k_{p h}$, and $k_{r}$ are not allowed to exceed 4 , and are chosen so as to maximize statistical fit.

\section{ESTIMATION RESULTS FOR THE G-5 ECONOMIES}

The estimates of $\beta, \gamma_{1}, \gamma_{2}$, and $\gamma_{3}$ for the G-5 economies using Equation (3) are shown in Table 2.

Table 2: Impact of Financial Factors on the Output Gap for G-5 Countries

\begin{tabular}{|c|c|c|c|c|c|c|c|c|c|c|c|c|c|c|c|}
\hline & \multicolumn{3}{|c|}{ United States } & \multicolumn{3}{|c|}{ United Kingdom } & \multicolumn{3}{|c|}{ Germany } & \multicolumn{3}{|c|}{ France } & \multicolumn{3}{|c|}{ Japan } \\
\hline Model & 1 & 2 & 3 & 1 & 2 & 3 & 1 & 2 & 3 & 1 & 2 & 3 & 1 & 2 & 3 \\
\hline \multirow{2}{*}{$\beta$} & $0.84^{* *}$ & $0.93^{* *}$ & $0.95^{* *}$ & $0.91^{* *}$ & $0.91^{* *}$ & $0.95^{* *}$ & $0.93^{* *}$ & $0.91^{* *}$ & $0.82^{* *}$ & 0.95 & 0.95 & $0.92^{* *}$ & 0.95 & 0.95 & $0.88^{* *}$ \\
\hline & 16.10 & 18.20 & 22.90 & 18.60 & 19.90 & 22.53 & 15.30 & 14.80 & 7.91 & 0.24 & 1.30 & 17.31 & 0.24 & 0.24 & 9.48 \\
\hline \multirow{2}{*}{$\gamma_{1}$} & $0.49^{* *}$ & & & $0.06^{*}$ & & & 0.12 & & & $0.08^{* *}$ & & & 0.06 & & \\
\hline & 4.89 & & & 2.22 & & & 1.49 & & & 3.19 & & & 1.01 & & \\
\hline \multirow{2}{*}{$\gamma_{2}$} & & $0.12^{* *}$ & & & $0.06^{* *}$ & & & 0.01 & & & $0.07^{*}$ & & & $0.13^{*}$ & \\
\hline & & 3.93 & & & 2.93 & & & 0.34 & & & 2.06 & & & 2.09 & \\
\hline \multirow{2}{*}{$\gamma_{3}$} & & & 0.00 & & & 0.00 & & & 0.10 & & & 0.04 & & & 0.11 \\
\hline & & & 0.00 & & & 0.00 & & & 0.89 & & & 1.29 & & & 1.29 \\
\hline $\mathrm{k}_{\mathrm{cr}}$ & 0 & - & - & 2 & - & - & 1 & - & - & 1 & - & - & 2 & - & - \\
\hline$k_{\mathrm{ph}}$ & - & 4 & - & - & 4 & - & - & 2 & - & - & 2 & - & - & 2 & - \\
\hline $\mathrm{k}_{\mathrm{r}}$ & - & - & 2 & - & - & 1 & - & - & 1 & - & - & 1 & - & - & 1 \\
\hline
\end{tabular}

Notes:

1. Figures under coefficient estimates are t-statistics; ${ }^{*}$-significant at .05, ${ }^{* *}$ - significant at .01 .

2. The following data ranges were used for estimating the model variants: (i) United States - Models 1 and 2, Q1 1980-Q4 2012; and Model 3, Q1 1975-Q4 2012; (ii) United Kingdom - Model 1, Q1 1963-Q4 2014; Models 2 and 3, Q1 1988-Q1 2015; (iii) Germany - Model 1, Q1 1991-Q4 2014; Model 2, Q1 2000-Q3 2014; and Model 3, Q1 1991-Q4 2007; (iv) France - Models 1 and 3, Q1 1970-Q4 2014; and Model 2, Q1 2000-Q3 2014; and (v) Japan Model 1, Q1 1977-Q1 2015; Model 2, Q1 2000-Q3 2014; and Model 3, Q2 1970-Q1 2015.

Source: Authors' calculations. 
Given estimates of $\beta$, we find that output gaps tend to be persistent in all G-5 economies regardless of the financial factor used. The estimates of $\beta$ using Models 1 and 2 for France and Japan are, however, not statistically different from zero. We also find that changes in real credit have positive and statistically significant effects on the output gap in the US, the UK, but not Germany and Japan. Changes in real property prices, on the other hand, have a statistically significant and positive impact on the respective output gaps in all G-5 countries, except Germany. The real interest rate does not have a statistically significant effect on the output gaps of any of the $\mathrm{G}-5$ economies.

Since we estimate the impact of changes in real credit, property price inflation, and real interest rate on the output gap separately, we select the model with an estimated financial factor coefficient that has the highest $t$-value the first stage, and make it the measurement equation in the estimation of potential output in the second stage. We then use the estimated potential output to compute potential output growth rates to compare them with actual output growth.

Figure 2 shows the plots of estimates of potential output growth using changes in real credit (Model 1) for the US, the UK, and Germany, and using property price inflation (Model 2) for France and Japan, together with actual output growth.

Figure 2: Actual and Estimated Potential Growth of G-5 Countries
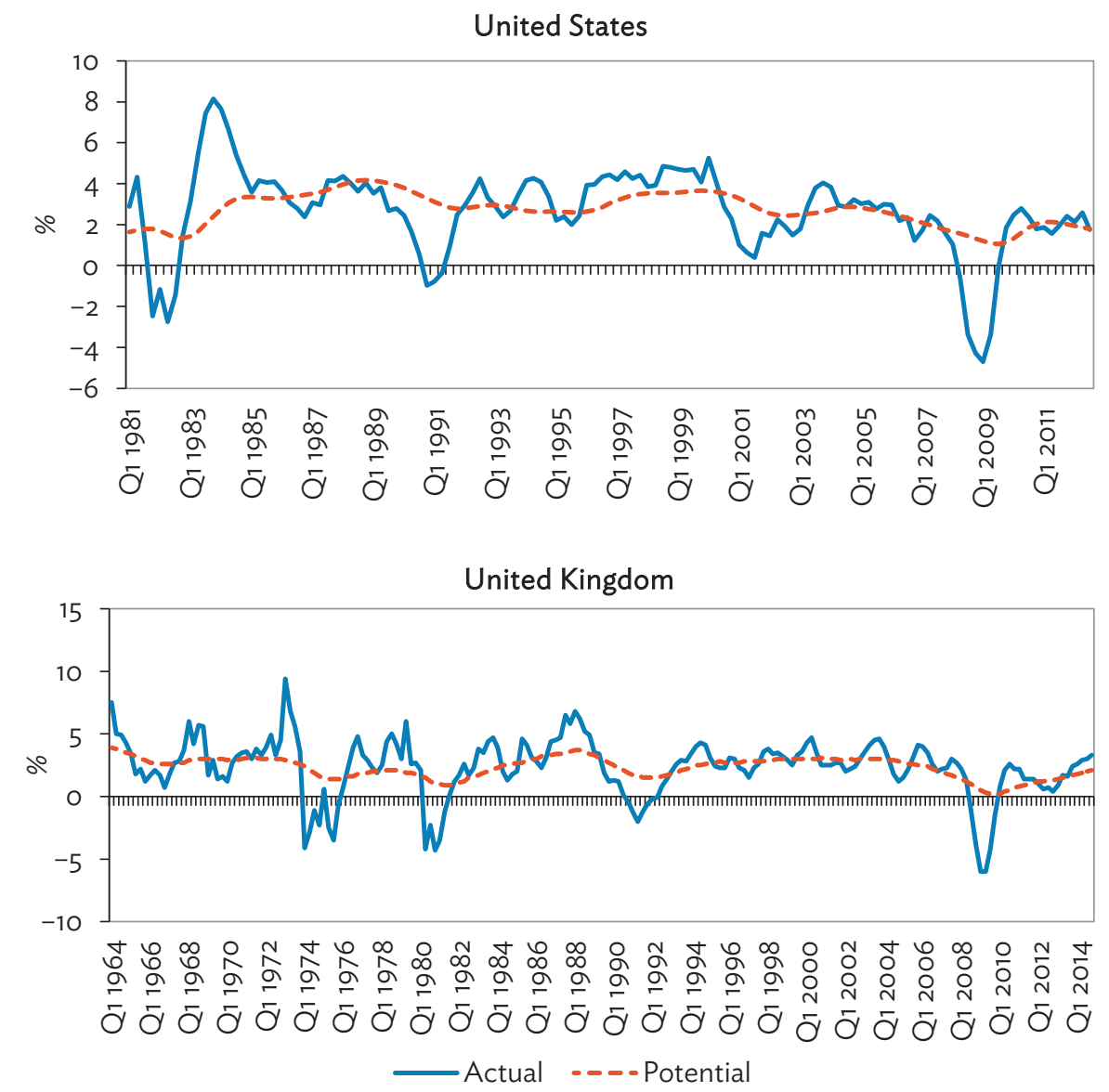

continued on next page 
Figure 2 continued

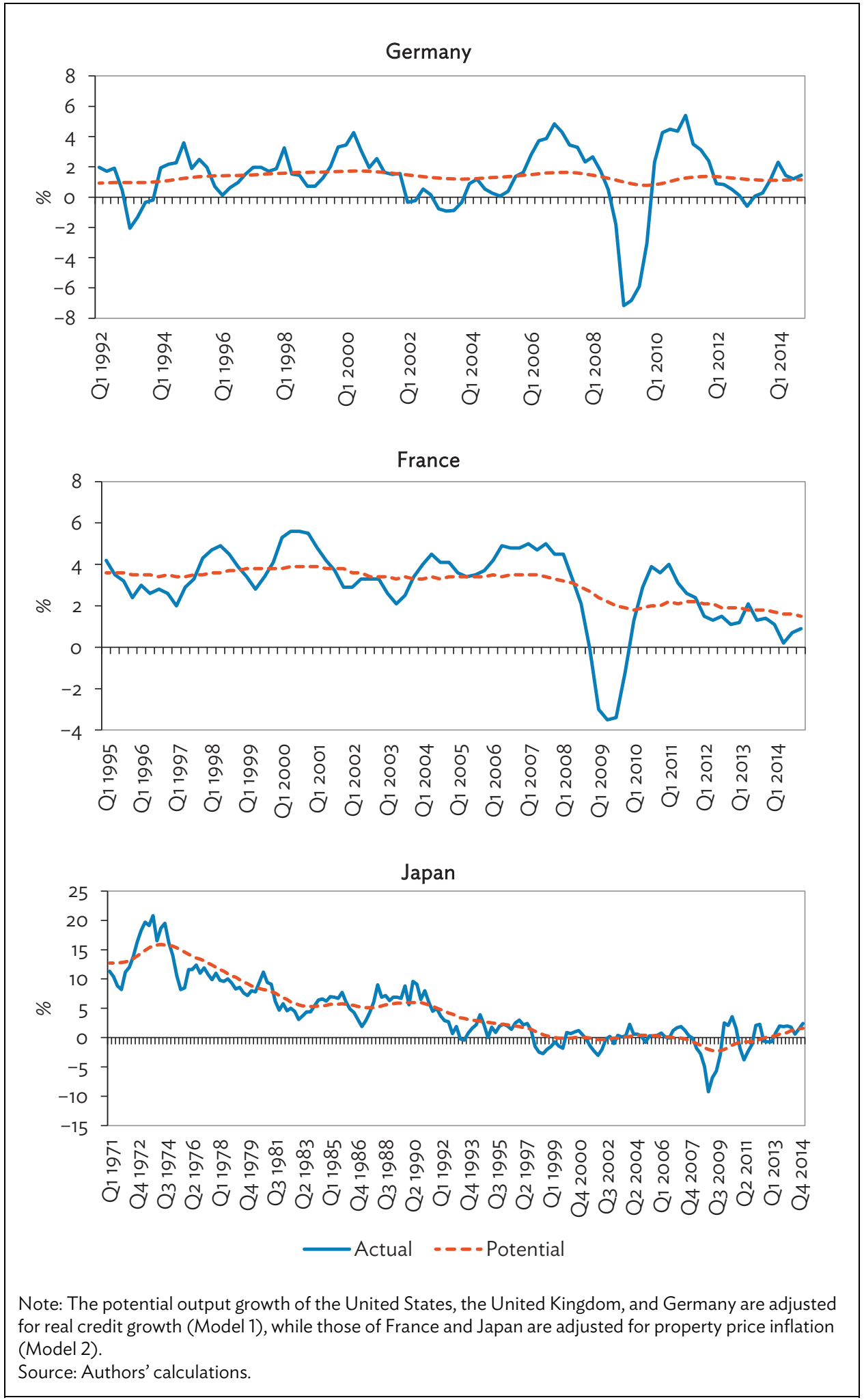

The charts show a general decline in actual and potential output growth during 2008-2009 due to the GFC. Potential output growth in the US has been on the decline following the technology 
bubble correction in 2002, and only recovered after the GFC. The UK's, France's, and to a much lesser extent Germany's, potential output growth, declined during the GFC. Germany's and the UK's potential output growth recovered rapidly, while France's stagnated at approximately $2 \%$ per annum, compared to its pre-GFC rate of over $3 \%$.

Table 3 shows the average actual and potential output growth rates before and after the GFC.

Table 3: Average Actual and Potential Output Growth of G-5 Countries

(\%)

\begin{tabular}{|l|c|c|c|c|}
\hline & \multicolumn{2}{|c|}{$2000-2007$} & \multicolumn{2}{c|}{$2008-2014$} \\
\hline Country & Actual & Potential & Actual & Potential \\
\hline United States & 2.55 & 2.38 & 0.58 & 1.69 \\
\hline United Kingdom & 2.97 & 2.80 & 0.57 & 0.90 \\
\hline Germany & 1.41 & 1.03 & 0.61 & 1.06 \\
\hline France & 4.06 & 3.53 & 1.31 & 2.09 \\
\hline Japan & -0.19 & 0.02 & -0.73 & -0.59 \\
\hline
\end{tabular}

Note: Model 1 is used for the United States, the United Kingdom, and Germany, while Model 2 is used for France and Japan. Source: Authors' calculations.

Average actual and potential growth during 2008-2014 declined relative to the pre-GFC rates during 2000-2007. The extremely low potential growth estimates for Japan is the result of its longterm deflationary environment, which began in the mid-1990s. We also note that the data for Germany is confined to the period after the reunification of Western and Eastern Germany in 1990.

\section{IV. $\quad$ ESTIMATION RESULTS FOR THE ASIAN ECONOMIES}

Using quarterly data, Equation (3) was likewise used to estimate the impact of real credit growth, property price inflation, and real interest rates on the output gaps of high-income economies of Asia. Table 4 shows the estimated models for the Republic of Korea; Hong Kong, China; Taipei,China; and Singapore using each finance factor separately as an explanatory variable.

We find that the estimates of $\beta$ are all significantly different from zero, and with the exception of Taipei,China, suggest that output gaps are highly persistent. The growth of real credit is found to have positive and highly significant effects on the output gaps of Singapore and Taipei,China. Real property price inflation tends to positively and significantly affect output gaps in these economies. Estimates of the coefficient of real interest rates, $\gamma_{3}$, are likewise positive, but statistically significant only for the Republic of Korea and Taipei,China. Overall, the findings suggest that financial factors tend to have positive influences on the output gaps of high-income economies in Asia.

Similar applications of the Borio, Disyatat, and Juselius (2013) framework to a group of Asian middle-income economies generally resulted in statistically insignificant estimates of the coefficients of the financial factors in Equation (3). Table 5 shows the results of estimates of Equation (3) for the PRC, Indonesia, Malaysia, the Philippines, Thailand, and India.

Similar to the G-5 and high-income economies in Asia, the estimates for $\beta$ on all model specifications, with the exception of Model 3 for Malaysia, are highly significant and suggest a high degree of persistence of output gaps. However, only Malaysia's growth in real credit has a statistically significant effect on its output gap. All other financial factors do not have any impact on the output 
gaps of Asia's middle-income economies. These findings, together with the evidence of a positive and statistically significant effect of financial factors on the output gaps of the G-5 and upper-income Asian economies, are consistent with the notion that financial factors tend to gain a more prominent role in output growth as economies develop. ${ }^{9}$

Table 4: Estimation Results: Impact of Individual Financial Factors for High-Income Asian Economies

\begin{tabular}{|c|c|c|c|c|c|c|c|c|c|c|c|c|}
\hline & \multicolumn{3}{|c|}{ Republic of Korea } & \multicolumn{3}{|c|}{ Singapore } & \multicolumn{3}{|c|}{ Hong Kong, China } & \multicolumn{3}{|c|}{ Taipei,China } \\
\hline Model & 1 & 2 & 3 & 1 & 2 & 3 & 1 & 2 & 3 & 1 & 2 & 3 \\
\hline & 0.84 & $0.80^{\prime \prime \prime}$ & $0.77^{*+1}$ & 0.89 & 0.87 & $0.91^{* n+4}$ & 0.88 & $0.87^{*}$ & 0.95 & 0.64 & 0.38 & $0.35^{* \prime}$ \\
\hline$\beta$ & 13.35 & 11.66 & 11.07 & 14.45 & 15.13 & 13.80 & 14.6 & 12.93 & 0.24 & 7.48 & 3.91 & 3.96 \\
\hline$\gamma_{1}$ & $\begin{array}{l}0.02 \\
0.99\end{array}$ & & & $\begin{array}{l}0.13^{*+1} \\
2.40\end{array}$ & & & $\begin{array}{l}0.03 \\
0.77\end{array}$ & & & $\begin{array}{l}0.52 \\
8.30\end{array}$ & & \\
\hline$\gamma_{2}$ & & $\begin{array}{l}0.11 \\
1.64 \\
\end{array}$ & & & $\begin{array}{l}0.08 \\
2.82\end{array}$ & & & $\begin{array}{l}0.09 \\
3.48 \\
\end{array}$ & & & $\begin{array}{l}0.27 \\
2.13\end{array}$ & \\
\hline$\gamma_{3}$ & & & $\begin{array}{l}0.04 \\
2.39\end{array}$ & & & $\begin{array}{l}0.12 \\
0.97\end{array}$ & & & $\begin{array}{l}0.05 \\
0.93\end{array}$ & & & $\begin{array}{c}0.0006 \\
2.98\end{array}$ \\
\hline $\mathrm{k}_{\mathrm{cr}}$ & 2 & - & - & 0 & - & - & 2 & - & - & 1 & - & - \\
\hline$k_{\mathrm{ph}}$ & - & 2 & - & - & 2 & - & - & 1 & - & - & 4 & - \\
\hline $\mathrm{k}_{\mathrm{r}}$ & - & - & 1 & - & - & 0 & - & - & 0 & - & - & 0 \\
\hline
\end{tabular}

Notes:

1. Figures under coefficient estimates are t-statistics; ${ }^{*}$ - significant at .10, ${ }^{* *}$ - significant at $0.05,{ }^{* *}-$ significant at 0.01 .

2. The credit and property price data used are from the Bank of International Settlements, except for Taipei,China whose credit and property price index data is from the International Monetary Fund and CEIC database, respectively. The real gross domestic product and consumer price index were downloaded from the CEIC database.

3. The following data ranges were used for estimating the model variants: (i) Republic of Korea - Model 1, Q1 1986-Q1 2015; Model 2, Q1 1963-Q4 2014; and Model 3, Q1 1978-Q1 2015; (ii) Singapore - Model 1, Q1 1975-Q1 2015; Model 2, Q1 1975-Q4 2014; and Model 3, Q1 1975-Q2 2013; (iii) Hong Kong, China - Model 1, Q4 1980-Q1 2015; Model 2, Q4 1978-2014Q4; and Model 3, Q4 1993-Q1 2015; and (iv) Taipei,China - Model 1, Q3 1982-Q1 2015; Model 2, Q3 1991-Q1 2015; and Model 3, Q3 1982-Q1 2015.

Source: Authors' calculations.

Table 5: Estimation Results: Impact of Individual Financial Factors for Middle-Income Asian Economies

\begin{tabular}{|c|c|c|c|c|c|c|c|c|c|c|c|c|c|c|c|}
\hline \multirow[b]{2}{*}{ Model } & \multicolumn{2}{|c|}{$\begin{array}{c}\text { People's Republic } \\
\text { of China }\end{array}$} & \multicolumn{2}{|c|}{ India } & \multicolumn{2}{|c|}{ Philippines } & \multicolumn{3}{|c|}{ Indonesia } & \multicolumn{3}{|c|}{ Malaysia } & \multicolumn{3}{|c|}{ Thailand } \\
\hline & 1 & 3 & 1 & 3 & 1 & 3 & 1 & 2 & 3 & 1 & 2 & 3 & 1 & 2 & 3 \\
\hline & 0.82 & 0.88 & 0.74 & 0.68 & $0.73^{\prime \prime \prime}$ & 0.87 & $0.90^{\prime}$ & 0.63 & 0.92 & 0.89 & 0.89 & 0.95 & 0.79 & 0.90 & 0.52 \\
\hline$\beta$ & 3.07 & 5.58 & 5.0 & 5.12 & 6.12 & 10.85 & 12.04 & 4.95 & 14.35 & 10.37 & 8.72 & 0.24 & 6.85 & 10.61 & 4.53 \\
\hline$\gamma_{1}$ & $\begin{array}{l}0.01 \\
0.44\end{array}$ & & $\begin{array}{l}0.02 \\
0.54\end{array}$ & & $\begin{array}{l}0.04 \\
1.16\end{array}$ & & $\begin{array}{l}0.0 \\
0.15\end{array}$ & & & $\begin{array}{l}0.12 \\
1.97\end{array}$ & & & $\begin{array}{l}0.06 \\
0.70\end{array}$ & & \\
\hline$\gamma_{2}$ & & & & & & & & $\begin{array}{l}0.06 \\
1.39\end{array}$ & & & $\begin{array}{r}0.18 \\
1.51\end{array}$ & & & $\begin{array}{l}0.0 \\
0.06\end{array}$ & \\
\hline$\gamma_{3}$ & & $\begin{array}{l}0.22 \\
0.92\end{array}$ & & $\begin{array}{l}0.67 \\
0.70\end{array}$ & & $\begin{array}{l}0 \\
0\end{array}$ & & & $\begin{array}{l}0.01 \\
0.36\end{array}$ & & & $\begin{array}{l}0.05 \\
0.78\end{array}$ & & & $\begin{array}{l}0.08 \\
0.22\end{array}$ \\
\hline $\mathrm{k}_{\mathrm{cr}}$ & 4 & - & 4 & - & 4 & - & 1 & - & - & 0 & - & - & 0 & - & - \\
\hline$k_{p h}$ & - & - & - & - & - & - & - & 3 & - & - & 0 & - & - & 0 & - \\
\hline $\mathrm{k}_{\mathrm{r}}$ & - & 1 & - & 3 & - & 1 & - & - & 4 & - & - & 4 & - & - & 0 \\
\hline
\end{tabular}

Notes:

1. Figures under coefficient estimates are t-statistics; ${ }^{*}$-significant at .05, ${ }^{* *}$ - significant at 01.

2. Model 2 was not estimated for the People's Republic of China, India, and the Philippines due to insufficient property price index data.

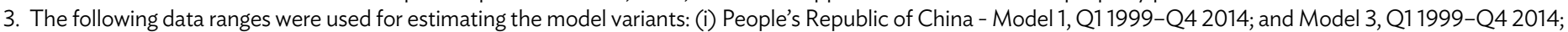

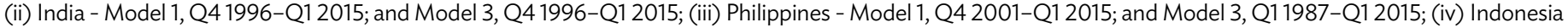
- Model 1, Q3 1983-Q4 2014; Model 2, Q1 2002-Q1 2015; and Model 3, Q1 1996-Q1 2015; (v) Malaysia - Model 1, Q4 1990-Q4 2014; Model 2, Q4 1998-Q4 2014; and Model 3, Q1 1996-Q1 2015; and (vi) Thailand - Model 1, Q1 1993-Q4 2014; Model 2, Q1 1993-Q2 2011 ; and Model 3, Q1 $1996-Q 12015$. Source: Authors' calculations.

9 See, for example, Cecchetti and Kharroubi (2015), and Rioja and Valev (2014). 
The estimated potential output growth for the upper- and middle-income Asian economies are shown in Figure 3, together with their respective actual gross domestic product growth rates.

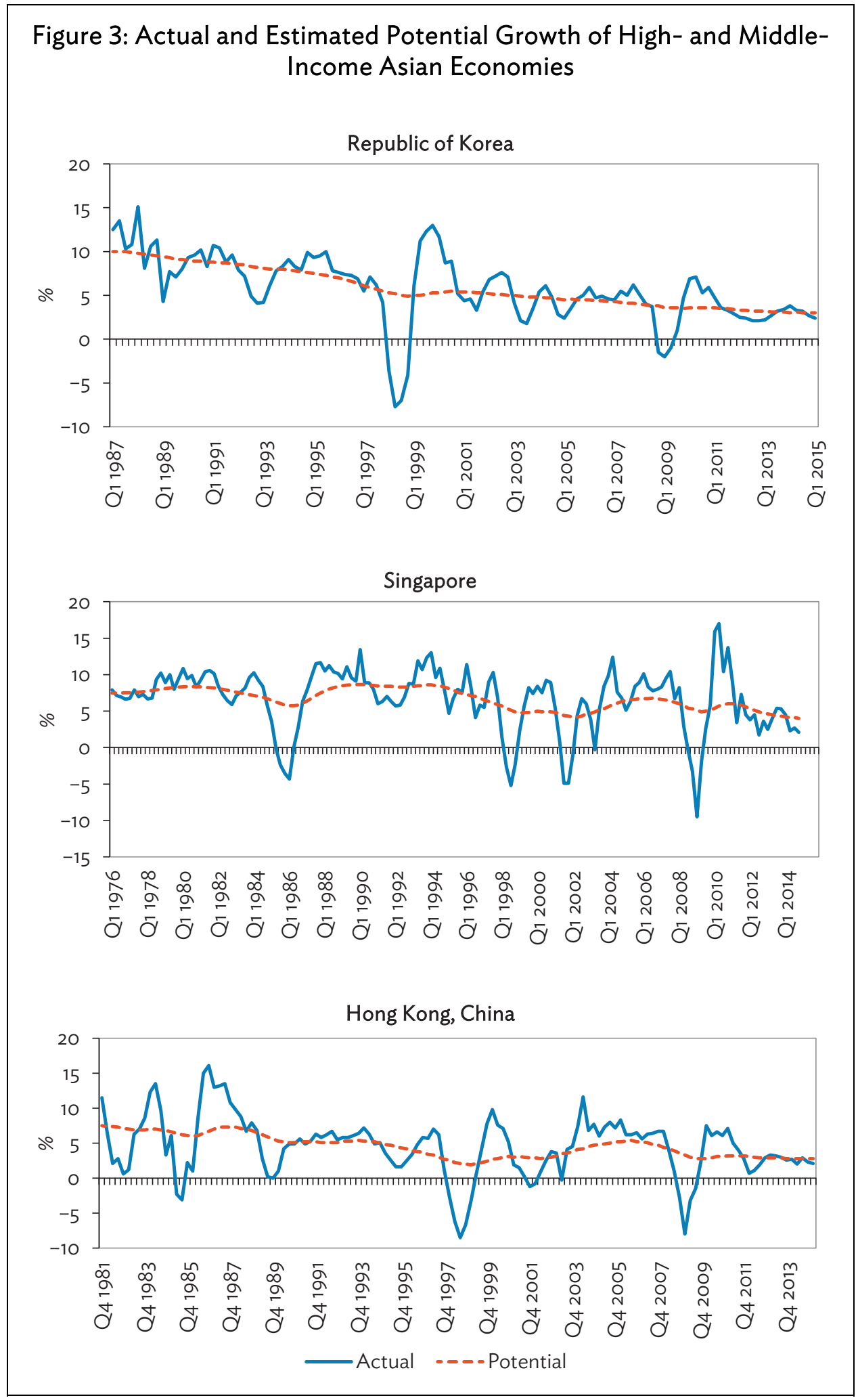

continued on next page 
Figure 3 continued

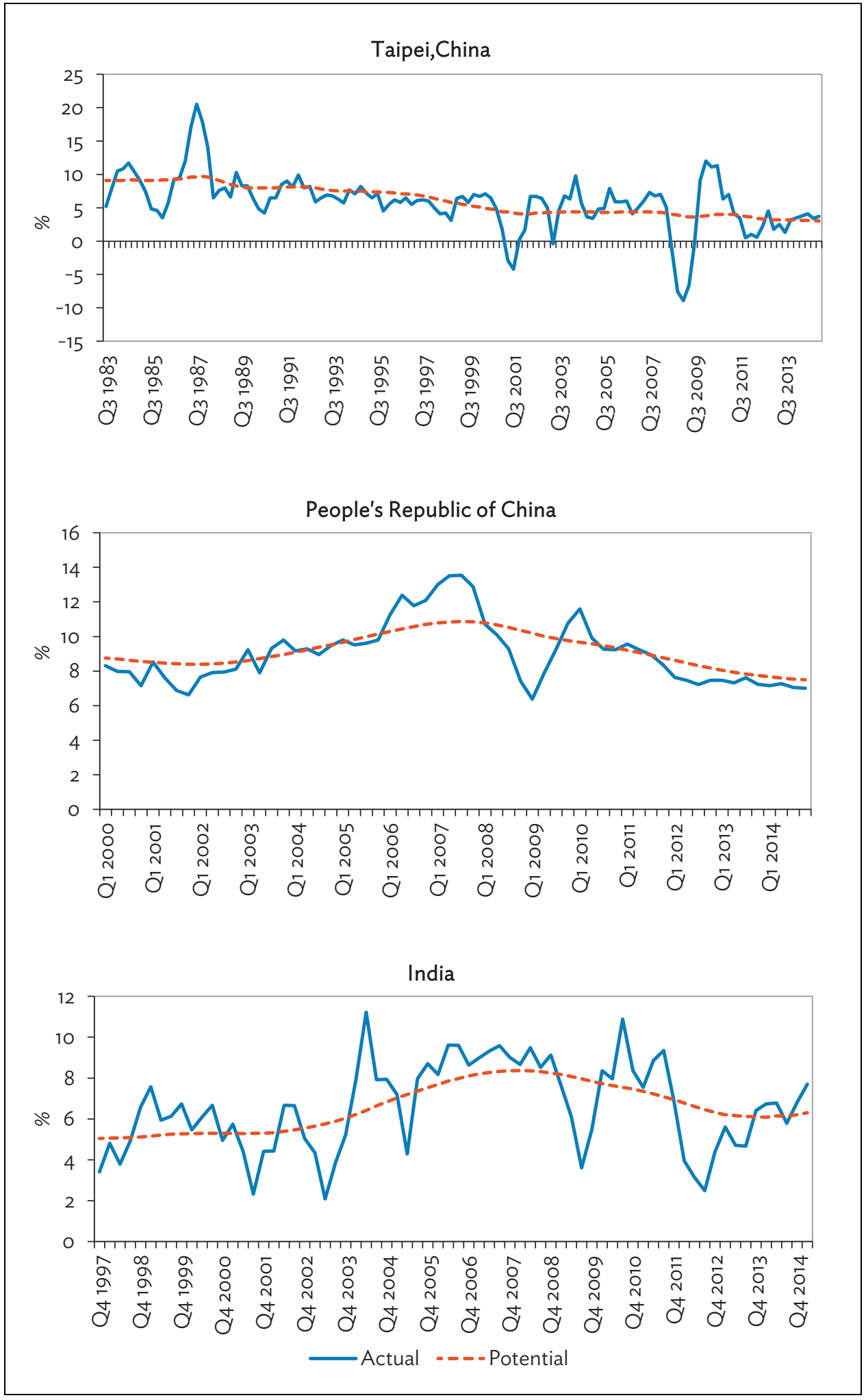

continued on next page 
Figure 3 continued

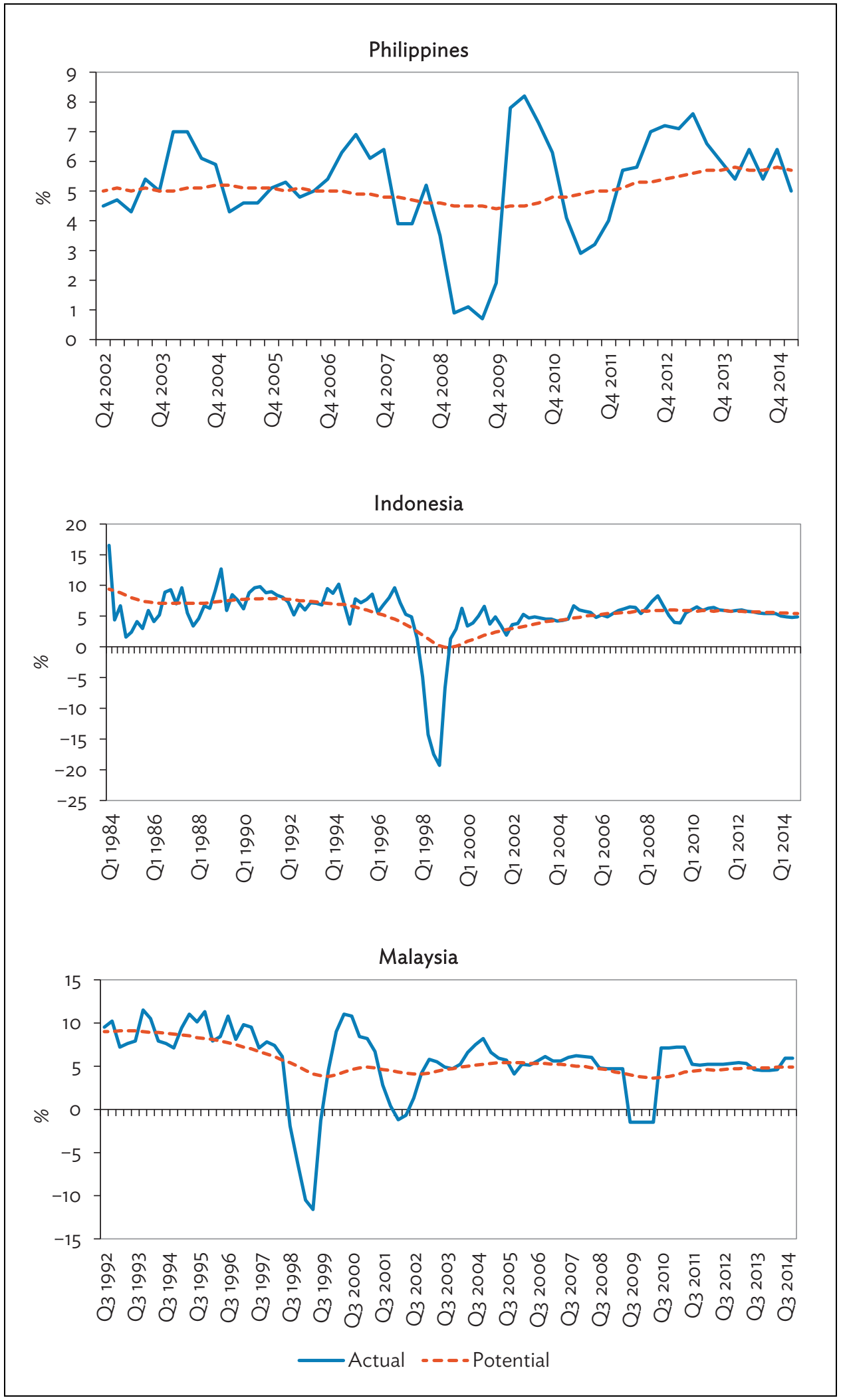

continued on next page 
Figure 3 continued

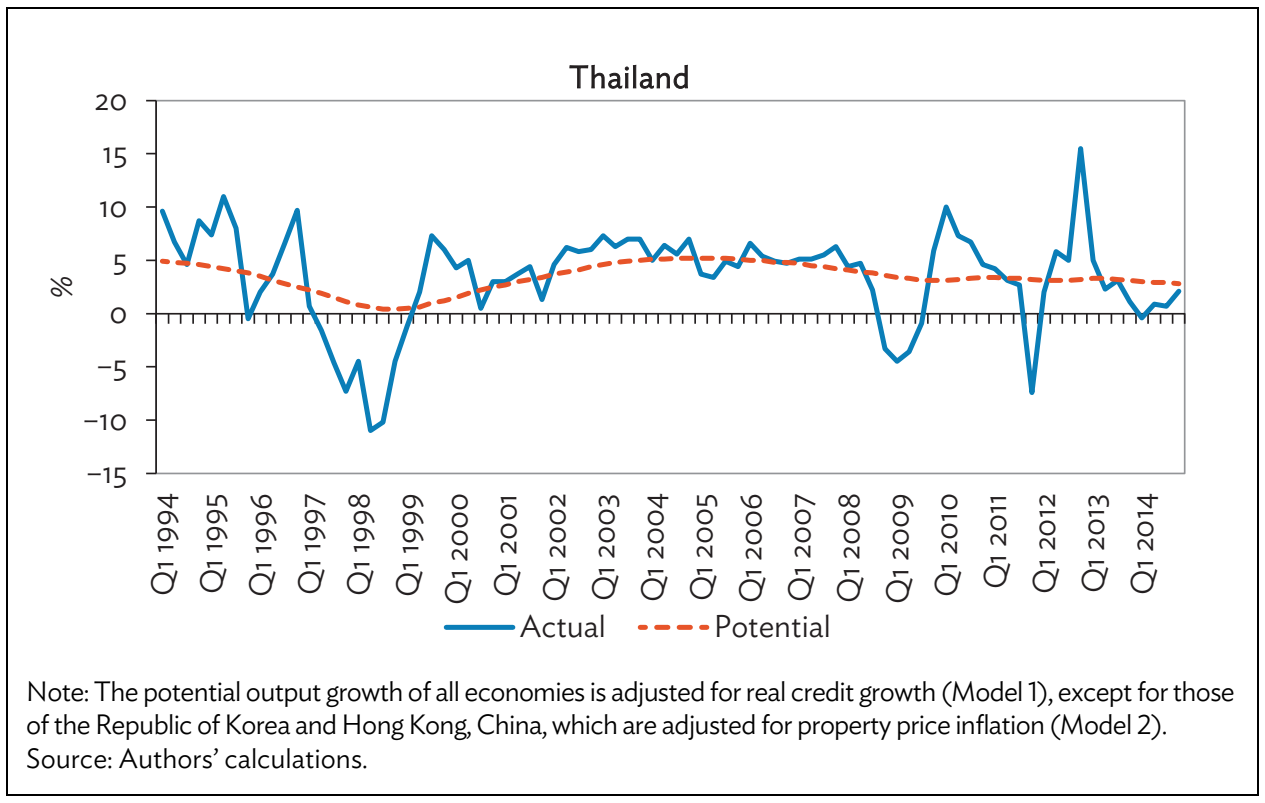

Table 6 shows the average actual and potential output growth rates of high- and middleincome income Asian economies before and after the GFC.

It is worth noting that the Asian Financial Crisis in 1997-1998 led to short-term reductions in the estimates of potential output growth of high-income Asian economies, following significant reductions in actual output growth. Potential output growth, however, generally rebounded after the AFC. The GFC has not impacted the potential output growth of the Republic of Korea and of Taipei,China, but has affected both actual and potential output growth of Hong Kong, China and Singapore.

Table 6: Average Actual and Potential Output Growth of Selected Asian Economies (\%)

\begin{tabular}{|c|c|c|c|c|}
\hline & \multicolumn{2}{|c|}{$2000-2007$} & \multicolumn{2}{|c|}{ 2008-2014 } \\
\hline & Actual & Potential & Actual & Potential \\
\hline \multicolumn{5}{|l|}{ High income } \\
\hline Republic of Korea & 5.26 & 4.82 & 3.12 & 3.42 \\
\hline Singapore & 6.19 & 5.57 & 4.57 & 4.10 \\
\hline Hong Kong, China & 5.26 & 4.81 & 3.12 & 3.42 \\
\hline Taipei,China & 4.72 & 4.39 & 3.00 & 3.61 \\
\hline \multicolumn{5}{|l|}{ Middle income } \\
\hline $\begin{array}{l}\text { People's Republic of } \\
\text { China }\end{array}$ & 9.53 & 9.36 & 8.42 & 8.99 \\
\hline India & 6.70 & 6.48 & 6.72 & 6.14 \\
\hline Philippines & 5.46 & 5.04 & 5.05 & 5.05 \\
\hline Indonesia & 4.90 & 3.96 & 5.74 & 5.77 \\
\hline Malaysia & 5.53 & 4.83 & 4.48 & 4.44 \\
\hline Thailand & 4.98 & 4.20 & 2.83 & 3.27 \\
\hline
\end{tabular}

Note: The potential output growth of all economies is adjusted for real credit growth (Model 1), except for those of the Republic of Korea and Hong Kong, China, which are adjusted for property price inflation (Model 2).

Source: Authors' calculations. 
We note that the estimates of potential output growth of the Republic of Korea and Taipei,China show a secular decline since the late 1980s. Those of Singapore and Hong Kong, China show similar declines, with the patterns of growth showing more cyclicality.

The estimates of potential growth for the PRC, India, and the ASEAN-5 (i.e., Indonesia, Malaysia, the Philippines, Thailand, and Singapore) show a mixed pattern. Potential growth increased during 2000-2007 in the PRC and India, and experienced a continuous decline during 2008-2014. The Philippines subsequently experienced stable potential output growth up to GFC, when potential growth marginally declined. Its potential growth increased during 2010-2014, to nearly 6\% per annum. Indonesia's potential output growth has been largely flat at $5 \%$ after recovering from a large dip during the AFC. Estimates of Malaysia's and Thailand's potential growth generally show the same pattern of movement, and differing only in the extent of growth declines due to the AFC and the GFC.

Note that, with the exception of the Philippines and Indonesia, all Asian high- and middleincome economies generally show similar patterns of declining potential output growth after the GFC. The extent of decelerations in potential growth differs across economies. Except for the Philippines and Indonesia, ${ }^{10}$ the average potential growth of all economies in Table 5 is lower in 2008-2014 compared to the averages in 2000-2007. Actual growth rates of output are similarly lower for 20082014, except for the Philippines, Indonesia, and India.

The largest declines in period averages of actual and potential output growth in 2008-2014 compared to 2000-2007 were in the Asian high-income economies. Thailand suffered a large decline in average actual and potential growth as well, although this is likely due to domestic sociopolitical developments.

\section{CONCLUSIONS}

The empirical evidence on the positive relationship between financial development and economic growth highlights the importance of financial factors in the estimation of output gaps and potential output. Adopting the framework proposed by Borio, Disyatat, and Juselius (2013), we estimate finance-neutral potential output growth for the G-5 economies and 10 high- and middle-income economies in Asia.

Using changes in real credit, property price inflation, and the real interest rate as proxy variables for the financial cycle, we find that the latter generally have statistically significant effects on the output gaps of the G-5 economies and the high-income economies of Asia, but not for the middleincome economies. Our findings are consistent with the literature on the nonlinear effects of finance on growth, and on the notion that the contribution of the finance sector to real economic growth only becomes important as economies reach a particular threshold of income.

We also note that the GFC affected the growth of potential output of the G-5 and in highincome economies in Asia, given their lower average potential output growth in 2008-2014 compared to their 2000-2007 averages.

10 The Philippines' actual and potential growth have been steadily increasing during 2010-2014 with improved macroeconomic fundamentals and its stable, low inflation environment. Indonesia's potential output growth, on the other hand, remained flat after recovering from the effects of the AFC. 


\section{REFERENCES}

Borio, C., P. Disyatat, and M. Juselius. 2013. Rethinking Potential Output: Embedding Information about the Financial Cycle. BIS Working Paper No.404. Bank of International Settlements.

2014. A Parsimonious Approach to Incorporating Economic Information in Measures of Potential Output. BIS Working Paper No.442. Bank of International Settlements.

Carlin W. and C. Mayer. 2003. Finance, Investment and Growth. Journal of Financial Economics. 69 (1). pp. 191-226.

Cecchetti, S. and E. Kharroubi. 2015. Why Does Financial Sector Growth Crowd Out Real Economic Growth? BIS Working Paper No.490. Bank of International Settlements.

Claessens, S., M. A. Kose, and M. Terrones. 2011. How Do Business and Financial Cycles Interact? IMF Working Paper No. 11-88. International Monetary Fund.

Jude, E. 2010. Financial Development and Growth: A Panel Smooth Regression Approach. Journal of Economic Development. 35 (1). pp. 15-33.

King. R. and R. Levine. 1993. Schumpeter Might be Right. The Quarterly Journal of Economics. 108 (3). pp. 717-37.

Law, S. H. and N. Singh. 2014. Does too much Finance Harm Economic Growth? Journal of Banking and Finance. 41 (C). pp. 36-44.

Okun, A. 1962. Potential GNP: Its Measurement and Significance. Cowles Foundation, Yale University.

Rioja, F. and N. Valev. 2004. Does One Size Fit All?: A Reexamination of the Finance and Growth Relationship. Journal of Development Economics. 74 (2). pp. 429-47.

Rosseau, P. and P. Wachtel. 2002. Inflation Thresholds and the Finance-Growth Nexus. Journal of International Money and Finance. 21 (6). pp. 777-93. 


\section{The Impact of Financial Factors on the Output Gap and Estimates of Potential Output Growth}

The authors examine the impact of financial factors on estimates of the output gap and potential output growth for the G-5 and 10 high- and middle-income Asian economies. Using a state-space model of the output gap with exogenously determined financial factors as regressors, they employ Bayesian methods to estimate the model parameters, and subsequently employ the Kalman filter to obtain estimates of potential output and potential output growth. They find that financial factors have positive and statistically significant effects on the output gap of the G-5 and high-income economies in Asia, but do not affect those of middleincome Asian economies. By accounting for the effects of financial factors on the output gap, the authors obtain finance-neutral estimates of potential output growth.

\section{About the Asian Development Bank}

ADB's vision is an Asia and Pacific region free of poverty. Its mission is to help its developing member countries reduce poverty and improve the quality of life of their people. Despite the region's many successes, it remains home to the majority of the world's poor. $A D B$ is committed to reducing poverty through inclusive economic growth, environmentally sustainable growth, and regional integration.

Based in Manila, ADB is owned by 67 members, including 48 from the region. Its main instruments for helping its developing member countries are policy dialogue, loans, equity investments, guarantees, grants, and technical assistance. 